\title{
Development of an innovative sandwich composite material for protection of lower limb against landmine explosion: mechanical leg test results
}

\author{
Mehmet Karahan' and Emir Ali Karahan²
}

\begin{abstract}
This paper includes results of the blast tests which were performed with the aim of comparing the energy absorption and protection efficiency of protective boots with different sole configurations. Tests were performed on a mechanical leg model vestured with protective boots. Load and three axis acceleration values were measured during the blast tests to determine the protection efficiency of boot samples. Herewith, it was understood that merely a monolithic composite layer used in a sole does not provide protection, whereas compressible metallic honeycomb material-based sandwich composites demonstrate better energy absorption. With the innovative sandwich composite material developed in this study, energy absorption was increased by $209 \%$ in comparison to monolithic composites.
\end{abstract}

\section{Keywords}

anti-personnel (AP) mine, boot, sandwich composite, mechanical leg

It is well known that anti-personnel (AP) landmines are a worldwide problem affecting many countries. Despite the recent attempts to prohibit the use of these weapons, there are still a large number of landmines on the field and stockpiled, which poses a constant threat to soldiers and civilians alike.

Even after years of research, no simple approach has been developed for protection against AP landmines due to the extreme loading which induces multiple damage mechanisms on the lower body. The main aim of protective boots or footwear against the landmines is to prevent the loss of the victim's foot, but if the damage is irreversible and traumatic amputation is necessary, the aim is to keep the amputated area as low as possible. From a wearer's perspective, the protective boots must be light and comfortable enough for operational use. More recently, textile structures produced with high-performance fibers have been used as reinforcement in the sole of footwear. The majority of this footwear relies on a combination of ballistic composites such as Aramid, Ultra High Molecular Weight Polyethylene (UHMWPE), honeycombed lightweight metals (to absorb or deflect blast). There are also designs that keep the feet off of the ground to increase the standoff distance, thus decreasing the effect of the blast wave.

The design of protective footwear against AP mines requires a specialized material design. The most widely used materials in such applications are fiber reinforced composites such as Kevlar or Dyneema, which can absorb the blast and provide enough ballistic strength to minimize any secondary shrapnel effect.

There are a few successful applications of anti-mine boots available in the defence industry. "Spider Boot", developed in order to protect against AP mines, is a commercialized design. ${ }^{1-3}$ This boot keeps the foot above the ground at a particular height. The pods of the boot press the ground away from the projection of the foot, which prevents the blast being directly below

\footnotetext{
'Uludag University, Vocational School of Technical Sciences, Gorukle Bursa, Turkey

${ }^{2}$ Department of Electrical and Electronics Engineering Bilkent University, Bilkent, Ankara, Turkey

Corresponding author:

Mehmet Karahan, Uludag University, Vocational School of Technical Sciences, Gorukle Bursa, TR-I6059, Turkey.

Email: mkarahan@uludag.edu.tr
} 
the foot. However, walking with these boots is difficult and running is almost impossible. A long period usage is not a possibility due to lack of mobility and comfort.

The boots, which are known as "Over Boots", are worn over a normal or a protective boot. This design keeps the feet above the ground by the thickness of boot sole. ${ }^{4,5}$ It is not suitable for usage over a long period, again owing to the lack of mobility.

More recent studies on protective boots generally focus on designs that look like a conventional army personnel boot. The early designs were reinforced with a metal plate in their sole. ${ }^{6,7}$ However, the existence of metal plate reduces the flexibility of the sole and increases the weight of the boot. Later studies have developed lighter constructions by using Kevlar and Dyneema fabric layers with light metal alloys. ${ }^{8,9}$ The boots built without using any metal reinforcement had multiple layers of Kevlar and Dyneema composite plates. ${ }^{10}$ In these designs, however, sole of the boot was not flexible because of the stiff composite layers. One of the commercially successful models developed by the Zeman Company, included Kevlar layers in the sole which provide protection to a maximum $50 \mathrm{~g}$ of AP mine. ${ }^{11,12}$ All of these studies show that the protective capability of the composite layers is limited as the transmitted force, which directly relates to the consequent injury, cannot be lowered by increasing the composite thickness or by using high-strength fibers owing to low compressibility under impulsive loads. The latest designs, therefore, have an energy-absorbing media below the composite layers to decrease the magnitude of the incident wave simply by inelastic deformation. ${ }^{13,14}$ Such parts are generally in the form of $\mathrm{V}$-shaped deflector in the sole to reflect the incident blast wave, and hence reduce the momentum transmitted to the feet. ${ }^{15}$

Common characteristics of protective boots or foot wears are that they have polymer composite materials in their sole against the blast effects. Yet only using the composite layers cannot provide sufficient energy absorption against the AP landmines. Using plastically deformable and compressible foam and honeycomb materials with composite layers considerably increases the ultimate energy absorption. ${ }^{16}$

The foremost aim of evaluating the protection against AP landmines is determining the possible injuries that can occur on limbs against the specific explosive/protective material. For this purpose, various test equipment and methods are being employed. It is a good approach to use strain-gauge, load cell and accelerometers to determine the forces exerted on legs during the blast in order to evaluate protection level. To this end, metal mechanical leg models were employed for several tests. With some existing studies ${ }^{17-20}$ in this scope load and strain transmitted to bones were retained.
Employing mechanical leg equipment, this study is focused on the comparison of the protection efficiency of monolithic and sandwich composite materials used in the boot sole.

\section{Materials and method}

\section{Sole and protective boots design}

The general appearance of the boots which were used in the tests is shown in Figure 1. According to this, the boot sole consists of two layers. The first one, which is the bottom part, has a deflector in order to deviate the shockwave. The second one, which is on the deflector, consists of the composite inserted plates. At the sole parts of the boots the deflector was kept the same, whereas the protective composite insert configurations were changed. The shoe-upper of the boot is strengthened by using 2-ply aramid woven fabric between the lining and leather.

The aim of this study was to examine energy absorptions and protection efficiency of different composite configurations in the boot sole, so that, keeping the deflector same, three different configurations of the composite layers were employed. Definitions of the samples which were used for the tests are given in Table 1. A deflector which was used at the mentioned samples consists of $2 \mathrm{~mm}$-thick steel plates and the inner parts were filled with $3 \mathrm{~mm}$ aluminum honey comb core. ${ }^{21}$ The top of the deflector was covered with a cover which consists of a $1 \mathrm{~mm}$ thick steel plate after placing the honeycomb inside the deflector. The deflector was placed on the boot's heel. Sizes and schematic representations of the deflectors are given in Figure 2. Properties of the deflectors and composite materials used in the sole are given at the Table 1 . The shoe vamp is consisted of three layers, the outermost of these is leather, the innermost layer is the lining and aramid fabric is used for reinforcement between leather and lining. Table 2 shows the materials used on the vamp of the boot.

Aramid UD fabric and ultra-high molecular weight polyethylene (UHMWPE) whose properties are given in Table 3, were used as reinforcement and nolax A21.2007 low-density polyethylene (LDPE) adhesive film (density $0.94 \mathrm{~g} / \mathrm{cm}^{3}$, melting temperature $80-90^{\circ} \mathrm{C}$ and melt flow rate of $6-9 \mathrm{~g} / 10 \mathrm{~min}$ ) was used as a matrix system. The properties of the fibers which were used in the preparation of reinforcement structures, are given in Table 4.

Three different types of composite configurations were used in the sole of the boot. On Type-1 boot only a monolithic composite insert was used in the sole. On Type-2, aluminum honeycomb was inserted between two layers of composite skins. Type- 3 is 

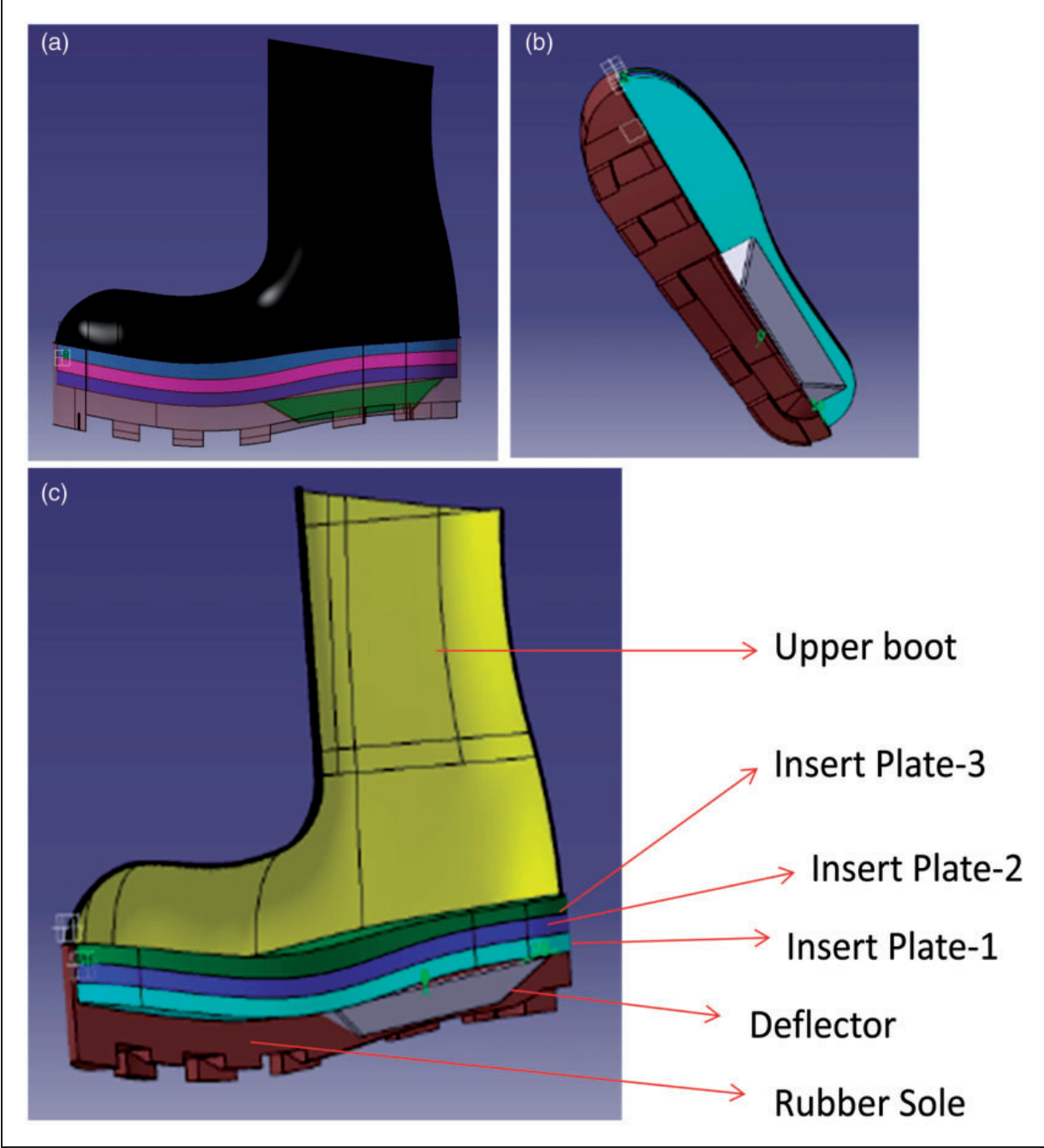

Figure I. Schematic views (a) and sole view of protective boots (b); Representative of boot segments (c).

Table I. Definition of the sole construction and production parameters of the boot samples used in this study (UD: Uni directional; UHMWPE: Ultra high molecular weight polyethylene)

\begin{tabular}{|c|c|c|c|c|c|c|c|c|c|c|}
\hline \multirow[b]{2}{*}{ Sample } & \multicolumn{4}{|c|}{ Deflector } & \multicolumn{2}{|c|}{ Insert plate-I } & \multicolumn{2}{|l|}{ Insert plate-2 } & \multicolumn{2}{|c|}{ Insert plate-3 } \\
\hline & Material & $\begin{array}{l}\text { Thickness } \\
(\mathrm{mm})\end{array}$ & $\begin{array}{l}\text { Taper } \\
\text { angle }\left({ }^{\circ}\right)\end{array}$ & $\begin{array}{l}\text { Height } \\
(\mathrm{mm})\end{array}$ & Material & $\begin{array}{l}\text { Plate } \\
\text { thickness } \\
(\mathrm{mm})\end{array}$ & Material & $\begin{array}{l}\text { Plate } \\
\text { thickness } \\
(\mathrm{mm})\end{array}$ & Material & $\begin{array}{l}\text { Plate } \\
\text { thickness } \\
(\mathrm{mm})\end{array}$ \\
\hline Type-I & Steel & $2 \pm 0.1$ & $106 \pm 3$ & $21 \pm 0.5$ & $\begin{array}{l}\text { UD aramid } \\
\text { plate }\end{array}$ & $10 \pm 0.5$ & $\begin{array}{l}\text { UD UHMWPE } \\
\text { plate }\end{array}$ & $5 \pm 0.2$ & $\begin{array}{l}\text { UD Aramid } \\
\text { plate }\end{array}$ & $5 \pm 0.2$ \\
\hline $\begin{array}{c}\text { Type-2 and } \\
\text { Type- } 3\end{array}$ & Steel & $2 \pm 0.1$ & $106 \pm 3$ & $21 \pm 0.5$ & $\begin{array}{l}\text { UD aramid } \\
\text { plate }\end{array}$ & $5 \pm 0.2$ & $\begin{array}{l}\text { Aluminum } \\
\text { honeycomb* }\end{array}$ & $2 I \pm 0.1$ & $\begin{array}{l}\text { UD aramid } \\
\text { plate }\end{array}$ & $5 \pm 0.2$ \\
\hline
\end{tabular}

*Honeycomb cells are filled with glass spheres in the Type-3 sample.

identical with Type-2, but aluminum honeycomb cells were filled with glass microspheres. Tables 5 and $6 \mathrm{dem}-$ onstrate the material properties of the aluminum honeycomb and glass microspheres.

\section{Protective boots manufacturing}

All composite plates used in the sole were produced by an autoclave process. The temperature of the process 


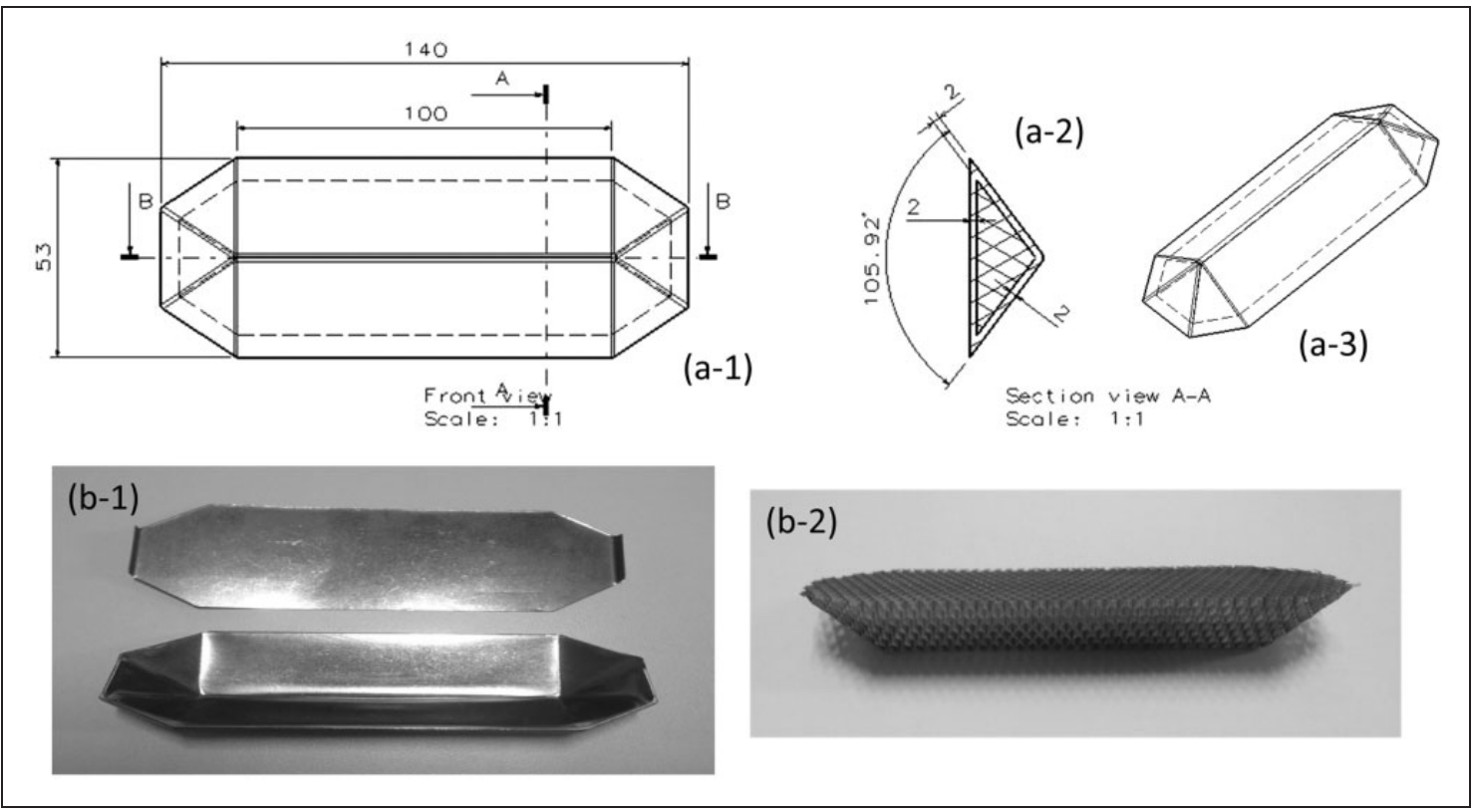

Figure 2. Views and sizes of deflectors. (a) Schematic representation and sizes of deflector; I, 2 and 3 indicate sizes on front view, cross-section and isometric view, respectively; (b) Real view of deflector; I shows the deflector outer body and top cover of deflector; and 2 shows the aluminum honeycomb core used in the deflector.

Table 2. Definition of the upper boot construction of the boot samples used in this study

\begin{tabular}{llllll}
\hline & \multicolumn{2}{l}{ Upper boot construction } & & & \\
\cline { 2 - 6 } Sample & Material & Type & $\begin{array}{l}\text { Number } \\
\text { of plies }\end{array}$ & $\begin{array}{l}\text { Total thickness } \\
(\mathrm{mm})\end{array}$ & Total weight $\left(\mathrm{gr} / \mathrm{m}^{2}\right)$ \\
\hline I. Layer (Outer) & Leather & Cowhide & I & $1.95 \pm 1.5$ & $350 \pm 0.5$ \\
2. Layer (Inner) & Aramid woven fabric & CT 736 & 2 & $1.2 \pm 0.2$ & $820 \pm 10$ \\
3. Layer (Inner) & Lining fabric & $\begin{array}{c}\text { \% I00 cotton } \\
\text { woven fabric }\end{array}$ & I & $0.2 \pm 0.1$ & $240 \pm 5$
\end{tabular}

Table 3. Properties of reinforcements used in the study (UD: Uni directional; UHMWPE: UHMWPE: Ultra high molecular weight polyethylene)

\begin{tabular}{|c|c|c|c|c|c|c|c|}
\hline $\begin{array}{l}\text { Reinforcement } \\
\text { type }\end{array}$ & Application & Weave type & $\begin{array}{l}\text { Linear density } \\
\text { of warp/fill } \\
\text { yarns, Tex }\end{array}$ & $\begin{array}{l}\text { Warp/fill } \\
\text { (or } 0^{\circ}-90^{\circ} \text { ) yarns }\end{array}$ & $\begin{array}{l}\text { Thread density, } \\
\text { threads } / 10 \mathrm{~cm}\end{array}$ & $\begin{array}{l}\text { Areal } \\
\text { density, } \\
\mathrm{g} / \mathrm{m}^{2}\end{array}$ & $\begin{array}{l}\text { Crimp warp/ } \\
\text { fill, \% }\end{array}$ \\
\hline $\begin{array}{l}\text { Aramid UD } \\
\text { sheet-GS3000 }\end{array}$ & $\begin{array}{l}\text { Composite } \\
\text { insert } \\
\text { in the sole }\end{array}$ & UD & $126 / 126$ & Kevlar 49/Kevlar 49 & - & 510 & Non-crimp \\
\hline $\begin{array}{l}\text { UHMWPE UD } \\
\text { sheet-H62 }\end{array}$ & $\begin{array}{l}\text { Composite } \\
\text { insert } \\
\text { in the sole }\end{array}$ & UD & $176 / 176$ & $\begin{array}{l}\text { Dyneema SK 62/ } \\
\text { Dyneema SK } 62\end{array}$ & - & 240 & Non-crimp \\
\hline $\begin{array}{l}\text { Aramid woven } \\
\text { fabric- CT } 736\end{array}$ & Upper boot & $\begin{array}{c}2 \times 2 \text { Basket } \\
\text { weave }\end{array}$ & $336 / 336$ & $\begin{array}{l}\text { Twaron } 2000 / \\
\text { Twaron } 2000\end{array}$ & $127 / 127$ & 410 & $0.8 / 0.8$ \\
\hline
\end{tabular}


Table 4. Parameters of the fibers used in the reinforcement fabrics (UHMWPE: Ultra high molecular weight polyethylene)

\begin{tabular}{|c|c|c|c|}
\hline Parameters & $\begin{array}{l}\text { Twaron } 2000^{\circledR} \\
\text { (Aramid) }\end{array}$ & $\begin{array}{l}\text { Kevlar } 49^{\circledR} \\
\text { (Aramid) }\end{array}$ & $\begin{array}{l}\text { Dyneema } \\
\text { SK } 62 \\
\text { (UHMWPE) }\end{array}$ \\
\hline Young modulus, GPa & 85 & 112 & 113 \\
\hline Strength, cN/Tex & 235 & 208 & 338 \\
\hline Ultimate elongation, \% & 3.5 & 2.4 & 3.6 \\
\hline Density, g/cm $\mathrm{cm}^{3}$ & 1.44 & $\mathrm{I} .44$ & 0.97 \\
\hline
\end{tabular}

Table 5. Parameters of the aluminum honeycomb material used in the sole of the boots

\begin{tabular}{ll}
\hline Parameters & Aluminum honeycomb \\
\hline Producer & Plascore \\
Type & PAMG-XRI 5056 \\
Cell size $(\mathrm{mm})$ & $3.175( \pm 10 \%)$ \\
Foil thickness $(\mathrm{mm})$ & 0.018 \\
Plate thickness $(\mathrm{mm})$ & 25.4 \\
True density $\left(\mathrm{g} / \mathrm{cm}^{3}\right)$ & $0.05( \pm 10 \%)$ \\
Compression strength $(\mathrm{MPa})$ & 2.34 \\
Compression modulus $(\mathrm{MPa})$ & 668.8 \\
\hline
\end{tabular}

Table 6. Parameters of the glass spheres materials used as filler in the honeycomb cells

\begin{tabular}{ll}
\hline Parameters & Glass sphere \\
\hline Producer & Cenosphere \\
Size (micron) & 100 \\
True density $(\mathrm{g} / \mathrm{cc})$ & $0.9-1.0$ \\
Bulk density $(\mathrm{g} / \mathrm{cc})$ & $0.45-0.50$ \\
Compression strength $(\mathrm{MPa})$ & $85 \pm 10$ \\
Float ratio $(\%)$ & 95 \\
\hline
\end{tabular}

was kept to $110^{\circ} \mathrm{C}$ and pressure of the vacuum to 14.8 bar during manufacturing. The composite plates have $65 \%$ fiber volume fraction approximately. Composite inserts and honeycomb were cut with water jets before the sole was assembled.

For production of boots, firstly the vamp part was sewn as aramid fabric between the leather and lining. Later on, the insert and deflector were assembled to each other and then to the vamp. Sikabond constructive adhesive was used to bond the insert, honeycomb and deflector. This component glue is an elastic adhesive and very suitable for ballistic applications. Sikabond construction adhesive is a one-component, gun-grade, adhesive and sealing compound of permanent elasticity. This dual-purpose material is based on a special moisture-cured polyurethane with an accelerated curing time. Having assembled the vamp, the deflector and insert were placed on the mold and rubber was injected into the mold. The injection method that squeezes the rubber material at high pressure into the sole mold produces a permanent highstrength bond between the upper and sole as the two parts are combined. After curing, edge burrs were removed. The manufacturing steps of the boots given in Figure 3.

\section{Mechanical leg and blast tests}

Denton Hybrid III Dummy mechanical lower leg model, which was attached to a test fixture, was used for the blast tests. The test fixture allows leg movement only in a vertical direction during the blast tests. The mechanical leg model was arranged to hold under $40 \mathrm{~kg}$ load, including its self-mass (Figure 4).

The mechanical leg model is equipped with a load cell and 3-axes accelerometers. The load cell was attached to the tibia axis. Two acceleration sensors were placed at the ankle and knee (Figure 5). Whereas the load cell can only get measurements from the tibia axis, acceleration sensors are able to gather 3-axis data. The properties of sensors are given in Table 7. A pressure sensor was placed on the test fixture one meter above from explosive material. A sensor was placed on the test fixture as it looks inwards and covered with tape. The exterior of the mechanical leg consists of removable vinyl skin/urethane foam. Wires used for data gathering were protected in hoses. An eight-channel LTT data acquisition system was used in the experiments.

After the mechanical leg was worn with boots, an explosive was placed on the soil ground as it centers the heel and barely touches it, which is considered to be worst case (Figure 6). The soil which was placed plastic container used for these tests was medium sand purchased in bags locally. The humidity level was very low (less than 1\%). 40 gram of TNT explosive was used on the tests. Tests were repeated four times for every sample and carried out at the General Security Department's blast test facility.

\section{Results and discussion}

\section{Load cell results}

A load cell was used on the tibia axis of the mechanical leg. The load cell was placed at a $150 \mathrm{~mm}$ distance from the explosive. With this load cell, only the force component in the direction of the tibia axis $F_{z}$ was 


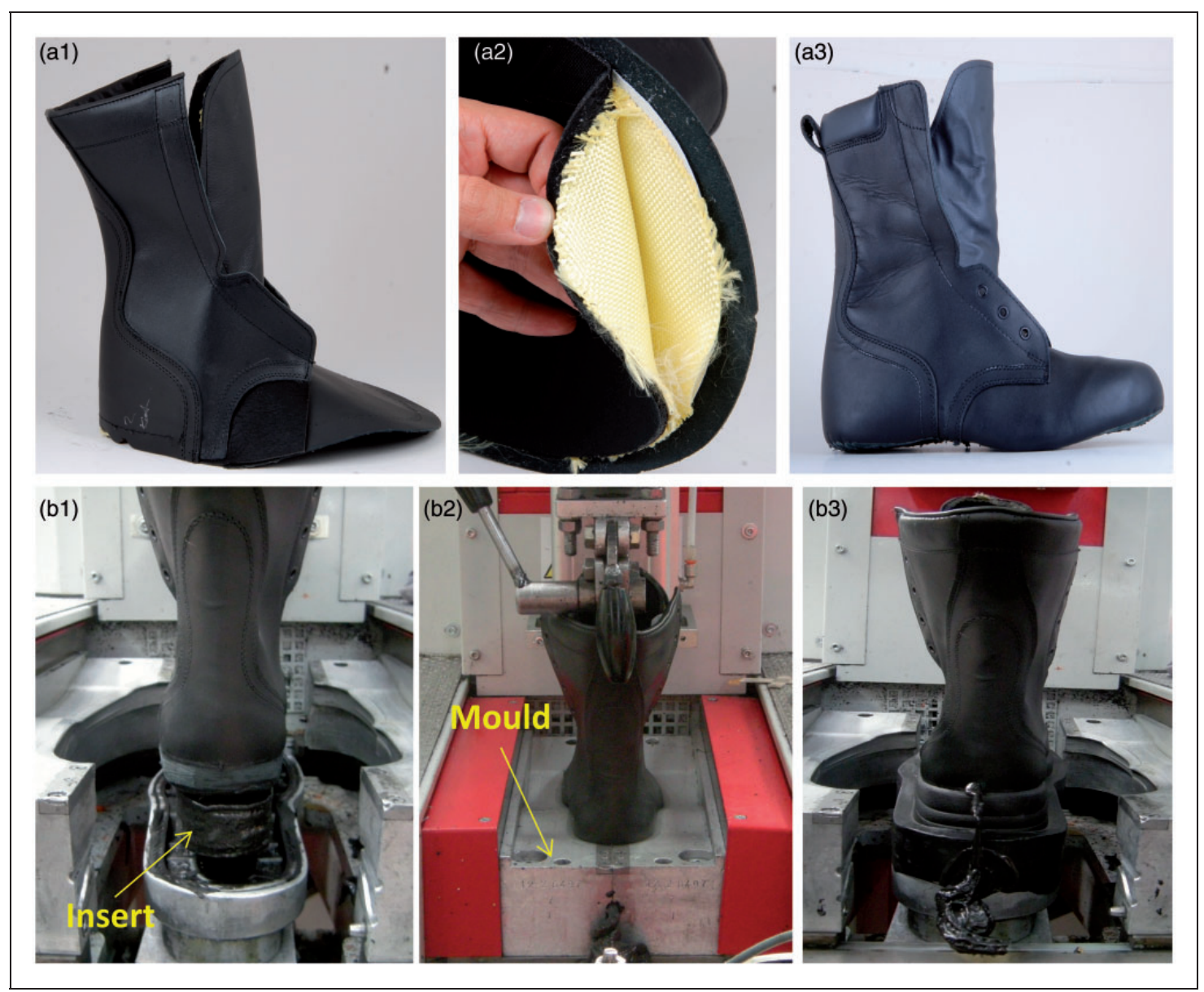

Figure 3. Manufacturing steps of the boots: (a) the vamp and (b) the rubber injection process.

measured. Table 8 shows maximum and minimum force values for different samples. All of the tests were performed under identical circumstances. The structure and sole heights of the boot samples were identical and only insert material in the sole differed. Thus, all samples can be compared between each other in a realistic manner for protection efficiency.

There is only a monolithic composite layer on Type-1 boot's insole. This monolithic composite plate is neither compressible nor deformable, meaning that it transmitted the force upwards directly during the blast. Herewith the measured value of the load $(442 \mathrm{kN})$ was considerably high. This situation implies if incompressible or non-deformable composites layers were to be used, no energy absorption ability would be observed. Figure 7(a) shows the boot's cross-section after blast for the Type-1 sample. According to this, since the boot was not compressed or deformed, it transmitted the blast load directly upwards, namely towards the tibia axis. This is the worst case for an injury. ${ }^{22}$

For efficient energy absorption, using just monolithic composite plate is not sufficient. Actually composite plates are needed for protection against fragments and other pieces stemming from the blast. However, deformable and energy absorber structures are necessary as well as composite layers. For this purpose, metallic foam and honeycomb materials are employed, in general. ${ }^{23-25}$ The Type-2 sample has a sandwich composite, having an aluminum honeycomb core between two composite skins in the sole. At first glance, the load cell results indicate that this structure has considerable effects on energy absorption. In comparison to the Type- 1 sample, force exerted on the tibia axis was decreased to $228 \mathrm{kN}$, in other words it was decreased $48 \%$. Compressibility of sandwich composite structure is demonstrated in Figure 7(b).

In Type-2 the total thickness of composite skins above and beneath the honeycomb core is less than the total thickness of the composite insert plate of Type-1. This situation has led to mass deficit. The Type-1 sample has showed no deformation, which indicates that its protection efficiency would be low. However, in the Type-2 sample, inelastic deformation of the honeycomb core granted more energy absorption and decreased the load transmitted to the tibia axis considerably. 


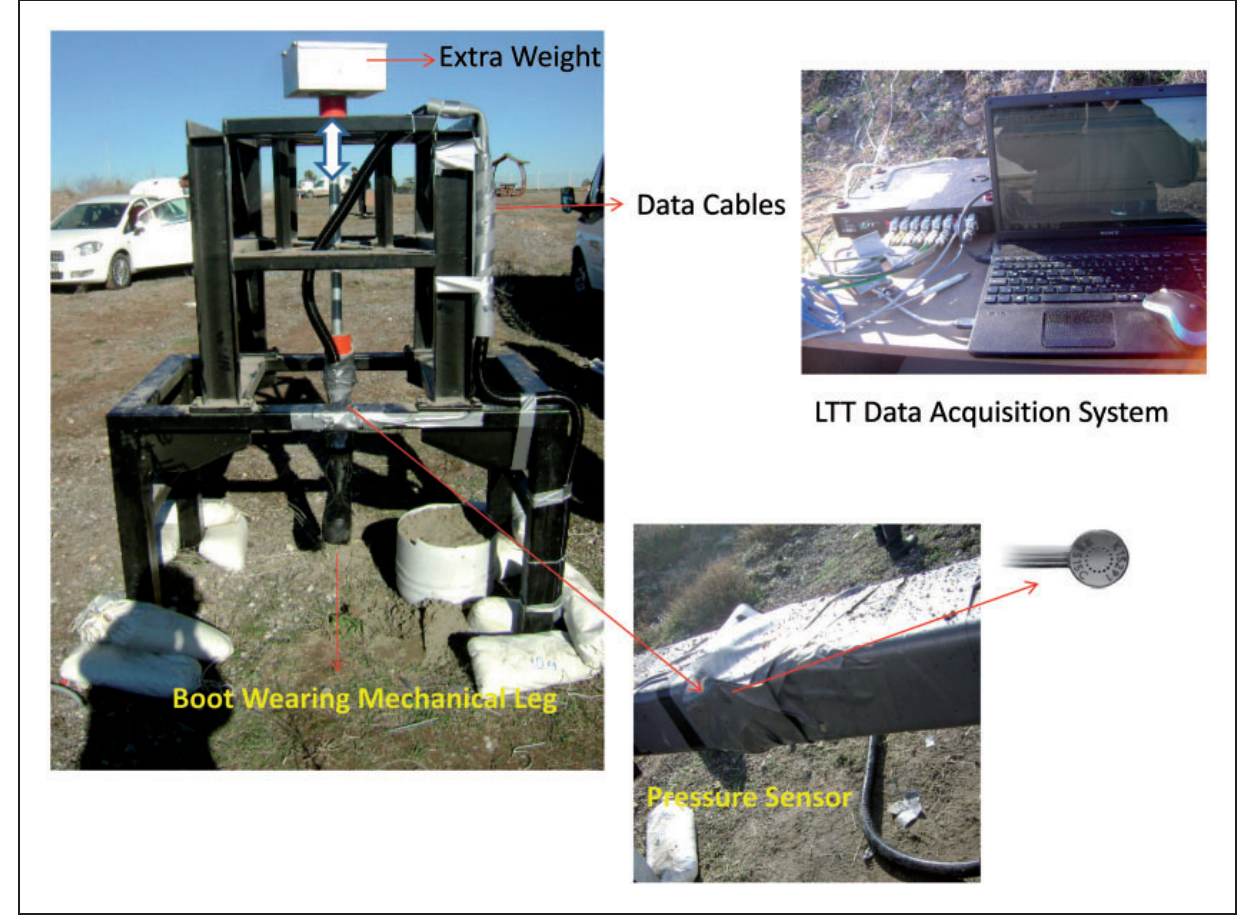

Figure 4. Total test set-up consisting of test frame, mechanical leg, sensors and data acquasition system.

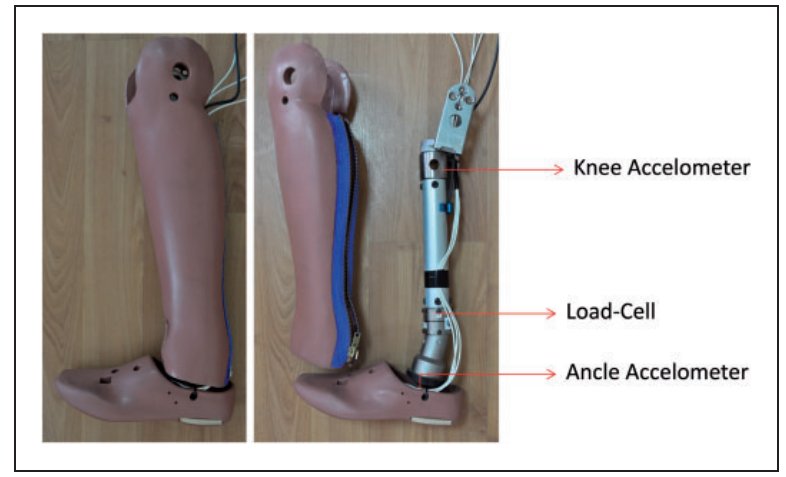

Figure 5. View of mechanical leg and location of the sensors.

Despite the aforementioned advantages of metallic honeycomb and foam core sandwich composites, their compression strength is very low. This is a reason for the limited energy absorption properties of these materials.

These materials compacted after compressing for a while under load and started transmitting the load directly. After compaction, the core behaves as a solid and there is no further absorption of the energy. ${ }^{26}$ Although there are different approaches for improving energy absorption capacity of these materials, many of these only concentrate on increasing the compression strength. For instance, corrugated and lattice truss
Table 7. Sensor properties used in the mechanical leg

\begin{tabular}{lll}
\hline Sensor & Type & $\begin{array}{l}\text { Measurement } \\
\text { Axes }\end{array}$ \\
\hline Load cell $(\mathrm{N})$ & PCB 200C50 & I-Axes \\
Ankle accelerometer $(\mathrm{g})$ & APTech-208I & 3-Axes \\
Knee accelerometer $(\mathrm{g})$ & APTech-208I & 3-Axes \\
Pressure sensor $(\mathrm{Pa})$ & Endevco & - \\
\hline
\end{tabular}

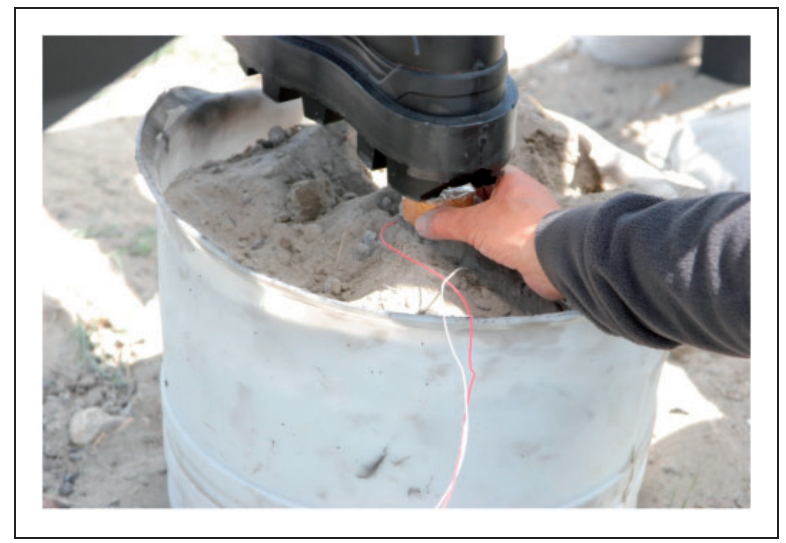

Figure 6. Explosive placement before the blast tests. 
Table 8. Blast test results

\begin{tabular}{|c|c|c|c|c|c|c|c|c|}
\hline & \multicolumn{2}{|l|}{ Load cell } & \multicolumn{2}{|c|}{ Ankle accelerometers (z-direction) } & \multicolumn{2}{|c|}{ Knee accelerometers (z-direction) } & \multicolumn{2}{|c|}{ Pressure sensor } \\
\hline & $\begin{array}{l}\text { Max. } \\
\text { load } \\
(\mathrm{kN})\end{array}$ & $\begin{array}{l}\text { Min. } \\
\text { load } \\
(\mathrm{kN})\end{array}$ & $\begin{array}{l}\text { Max. } \\
\text { acceleration } \\
\text { (g) }\end{array}$ & $\begin{array}{l}\text { Min. } \\
\text { acceleration } \\
\text { (g) }\end{array}$ & $\begin{array}{l}\text { Max. } \\
\text { acceleration } \\
(\mathrm{g})\end{array}$ & $\begin{array}{l}\text { Min. } \\
\text { acceleration } \\
\text { (g) }\end{array}$ & $\begin{array}{l}\text { Max } \\
\text { pressure } \\
(\mathrm{kPa})\end{array}$ & $\begin{array}{l}\text { Min. } \\
\text { pressure } \\
(\mathrm{kPa})\end{array}$ \\
\hline Type I & $442 \pm 27$ & $-424 \pm 69$ & $2042 \pm 183$ & $-986 \pm 112$ & $1906 \pm 229$ & $-1023 \pm 167$ & $74.2 \pm 5.8$ & $-22.3 \pm 6.1$ \\
\hline Type 2 & $228 \pm 14$ & $-11.6 \pm 4$ & $1166 \pm 101$ & $-776 \pm 52$ & $1129 \pm 147$ & $-685 \pm 29$ & $78.5 \pm 6.2$ & $-20.4 \pm 5.5$ \\
\hline Type 3 & $143 \pm 12$ & $-6.5 \pm 5$ & $862 \pm 54$ & $-507 \pm 4 I$ & $907 \pm 83$ & $-466 \pm 57$ & $71.6 \pm 4.0$ & $-28.6 \pm 3.2$ \\
\hline
\end{tabular}

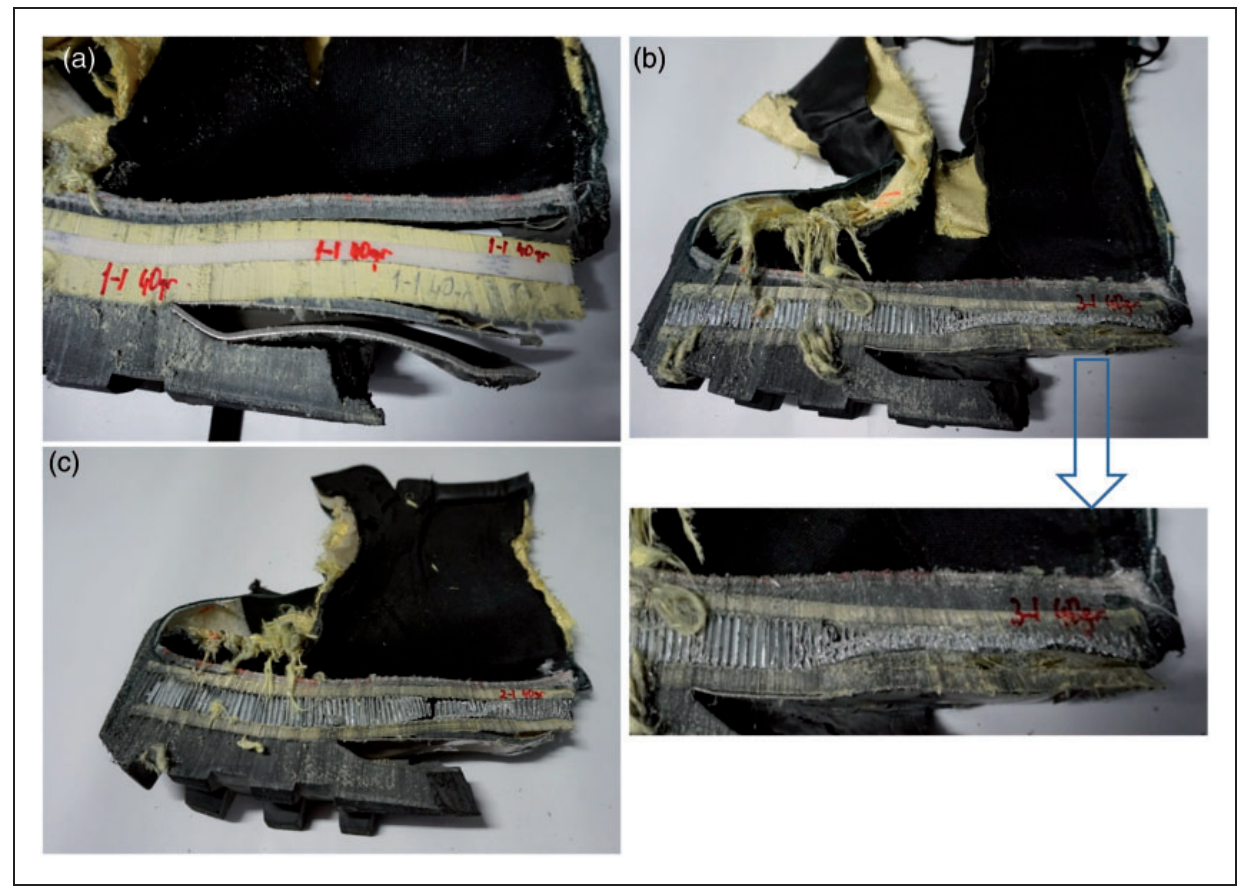

Figure 7. Cross-section view of the samples after the blast tests: (a) Type-I; (b) Type-2; and (c) Type-3.

cores are more advantageous owing to their higher compression strength. ${ }^{25,26}$ Yet their cost is higher and manufacturing them is difficult. Another approach is filling the honeycomb cells with foam which is the most outstanding solution. ${ }^{27,28}$ Yet this method provides only a limited improvement for compression strength.

In this work, the effect of glass microspheres on energy absorption capability of metallic honeycomb core composites is studied as well. To do this, cells of honeycomb core were filled with glass microspheres to about $75 \%$ of cell height, different from Type- 2 . Test results indicate that glass microspheres are quite efficient regarding energy absorption of metallic core sandwich composites. According to the results obtained, energy absorption was increased dramatically by using glass microspheres in the honeycomb cells. The load transmitted to tibia axis was decreased $209 \%$ in comparison with Type-1 sample and decreased to $143 \mathrm{kN}$. About $59 \%$ decrease was achieved compared to Type-2 whose cells were completely empty. Load data for Type-3 were significantly lower than data from a previous study with the same amount of explosive. ${ }^{22}$ Figure 8 (a) provides a comparison of load data for three samples. Figure 7(c) shows the cross-section of the Type- 3 sample after blast. Although, the crosssection does not display a significant difference with Type-2, compression occurred more uniformly in comparison to Type-2. This case indicates that glass microspheres spread the blast shock wave to a larger plane. The energy absorption mechanism of the glass microspheres can be explained with breakage of the spheres at the first stage and then distorting the energy via sliding over each other. However, an impact of about $59 \%$ shows that there can be different energy absorption mechanisms. No studies were found 


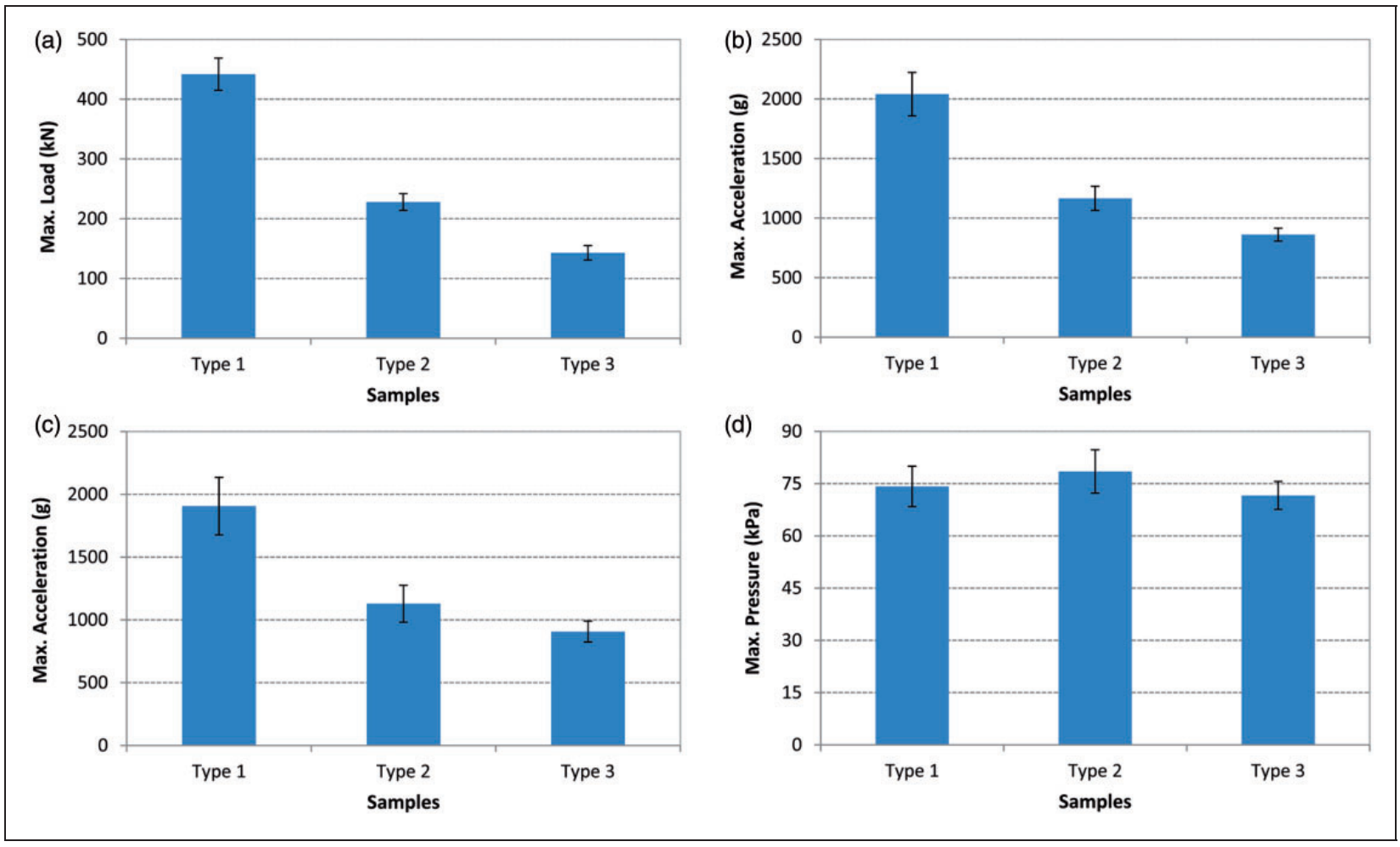

Figure 8. Comparison of peak load (a), ankle (b) and knee peak acceleration (c) and peak pressure (d) data of different samples.

on this issue; however, it can be assumed that, owing to sudden compression under blast shock, glass can absorb more energy via glass transition softening mechanisms. Glass microspheres are considered to be semiamorphous and semi-crystalline, they undergo phase transformation even at room temperature under high pressure. This phase transformation of amorphous structure is called glass-liquid transition or briefly glass transition. The glass transition, which is a shortterm and reversible reaction, is normally defined as the passage from a semi-crystalline structure to the semiliquid phase below melting temperature without any melting. Under a great pressure wave such as explosion, glass microspheres can perform this phase transition. Owing to generally solid-liquid phase transition is endothermic reactions, glass microspheres exhibit significantly energy absorber characteristic. ${ }^{29}$ Since glass microspheres are too light, easily affordable and applicable for sandwich composites, they show significant energy absorption. This will a quite innovative and remarkable development for energy-absorbing materials. Their energy absorption mechanism will be investigated and clarified in future works.

For each sample load-time curves show quite different characteristics. Actually curves also explain the energy absorption capacity of the samples. Figure 9 shows the load-time curve of the Type-1 sample. In this sample, two peak load points were reached during the blast. The first of these occurred at $0.025 \mathrm{~ms}$. The zone observed before reaching the maximum load is where the deflector distorted the shock wave and absorbed a portion of blast energy, so peak load was reached with delay. After the first peak load, the force value also reached a negative peak. This situation normally occurs owing to a negative pressure effect. During such a negative phase, a partial vacuum is created and air is sucked in. This is also accompanied by high suction winds that carry the injurious effect as a positive force. ${ }^{30}$ After $0.025 \mathrm{~ms}$. where load was transmitted in an upwards direction, a shock wave was observed to be moved along without energy absorption. Because the peak load value at this point is nearly equal to the first peak load value, the second peak value was reached at $0.1 \mathrm{~ms}$. Following this, maximum negative load occurs again and after $0.15 \mathrm{~ms}$. load fell to about zero, owing to the shock wave ending. The load-time curve indicates that no means of energy absorption happens on the boot sole after deformation of the deflector for the Type-1 sample.

The load-time curve for the Type- 2 sample is quite different (Figure 10). Reaching the first peak value of load is different from the Type-1 sample. Similar to Type-1, peak load was reached without a necessary time for deformation of the deflector. Time for reaching the peak load was $0.015 \mathrm{~ms}$. The reason for the decrease in time required for reaching peak load was that the 


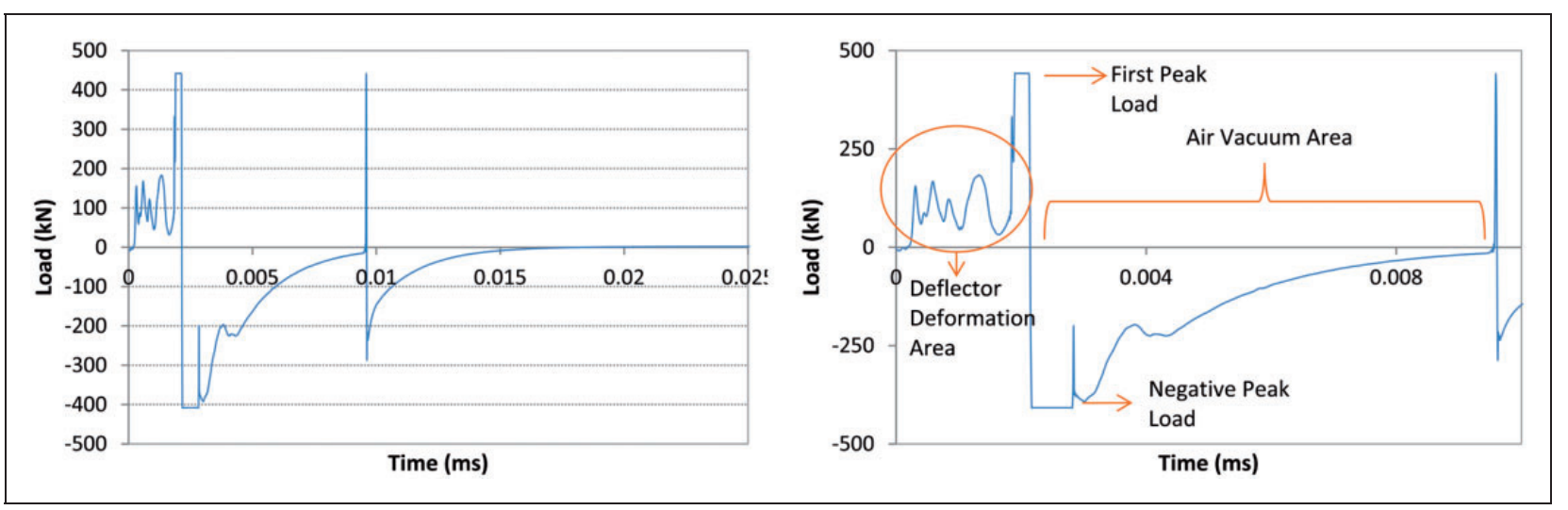

Figure 9. Typical load-time curve of sample Type-I.

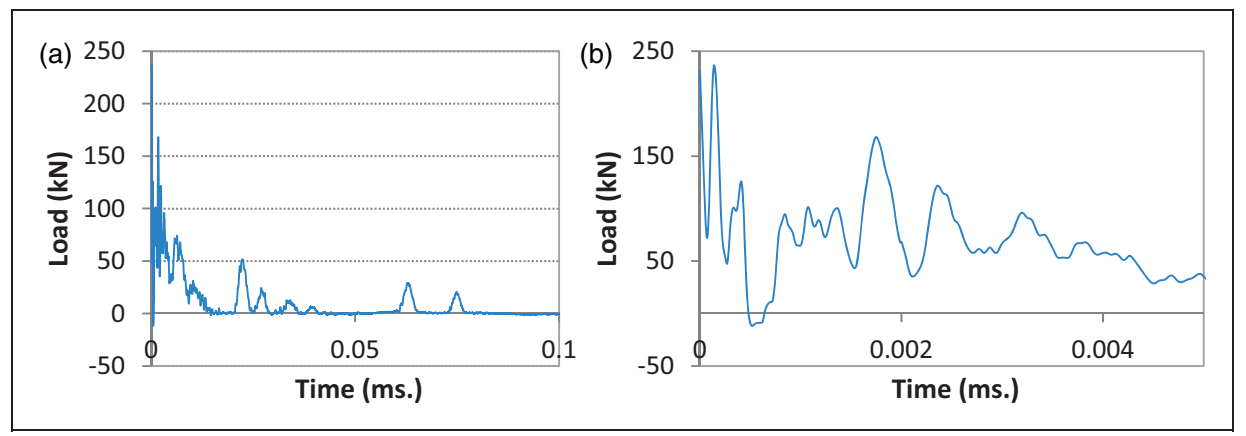

Figure 10. Typical load-time curve of sample Type-2.

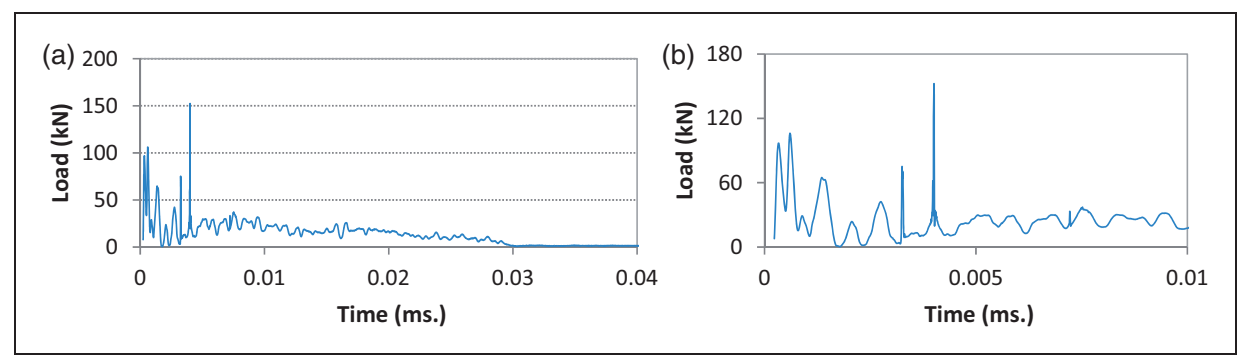

Figure II. Typical load-time curve of sample Type-3.

honeycomb material between the composite layers and deflector started to deform simultaneously owing to the shock wave's sudden blast effect. In other words, whereas the deflector was deforming, the honeycomb material also began to deform simultaneously. This deformation continued gradually. Excessive oscillations after peak load value were attributable to compression of the honeycomb core material. After reaching the first peak, the negative peak value was observed to be very small since blast energy was absorbed by the honeycomb core's deformation. Peak load values that were observed later decreased gradually and blast was damped efficiently. The impact of injuries would be decreased since no negative load value was observed on the load-time curve.

The load-time curve of Type-3 sample shows some specific differences with Type-2 (Figure 11). First of all, the time needed for reaching the peak load value was delayed critically. Peak load was reached at $0.04 \mathrm{~ms}$. Before this point, the curve follows an oscillatory path, possibly the deflector and honeycomb core between composite skins were deformed before reaching the peak load. The peak load remained for a very short time and the load level decreased quickly. 
Fluctuations on the curve point towards a serious deformation and energy absorption on the boot sole. However, a complex load-time curve was observed for this sample since both honeycomb core and glass microspheres were deformed simultaneously. Also, we can conclude that energy was absorbed in a more efficient way since no negative load occurred. Load was completely absorbed after $0.3 \mathrm{~ms}$. later. Since the damping period of load was long, reaching the peak value was delayed, time remaining around peak load value was too short and the negative peak load was avoided, the protective efficiency of Type-3 sample was proved to be the best.

According to the blast test results, in the Type-1 sample, the explosion load was transferred in the upward direction directly owing to non-compressible properties of the composite plates in the sole. The Type- 2 and Type- 3 samples absorbed more energy, owing to inelastic deformation of the honeycomb core in the sole. For these samples, the shock load was delayed and shock amplitude was reduced as well. Thus, more kinetic energy was absorbed.

\section{Acceleration and pressure data}

Acceleration as well as force measurements are important for evaluating boots' protection efficiency or possible physical injuries since they indicate transmission speed of the shockwave. For this reason three-axis acceleration data were gathered from both ankle and knee alignment. Among these the-axis data, since more dominant loading occurred along $z$-axis, the influence of acceleration in this direction is more important than others. Keeping in view this aspect, only acceleration values in the $z$ direction were taken into consideration.

Data obtained from ankle alignment differed among sample types. While acceleration along the $z$ axis was measured as $2041 \mathrm{~g}$ for Type- 1 sample, decreasing $43 \%$ acceleration diminished to $1166 \mathrm{~g}$ for the Type- 2 sample. For the Type-3 sample acceleration decreased $136 \%$ relative to Type- 1 and $35 \%$ relative to Type- 2 and fell to 862 .

Although it is farther from explosive, acceleration values obtained from the knee are quite close to the data gathered from the ankle. However, the influences of sample change on these values were significantly different. While the $z$-axis of the acceleration observed around the knee was measured as $1906 \mathrm{~g}$ for the Type- 1 sample, it decreased by $40 \%$ and fell to 1129 for the Type- 2 sample. For the Type-3 sample the acceleration value decreased by $110 \%$ relative to Type- 1 and $24 \%$ relative to Type- 2 and fell to 907 . Figure 8 (b) and (c) show peak acceleration values obtained from the ankle and knee, respectively.
Acceleration curves show different characteristics. Acceleration curves of Type- 2 and Type- 3 follow more oscillation path owing to core deformation (Figure 12).

Honeycomb and glass microspheres used on the boot sole caused a considerable decrease in acceleration values as well as load values. The characteristics of acceleration-time curves do not differ for samples. For example, the acceleration-time curve obtained only from ankle alignment is given in Figure 12.

Pressure data were collected in order to determine outdoor pressure within 1 meter distance from the explosive. Pressure was measured quite close for all three samples. Herewith, we concluded that difference of sample type has no influence on pressure values. For all three samples, the time needed for reaching peak pressure value and damping of the pressure was nearly same. For all three sample comparisons of pressure values are given in Figure 8(d). Characteristic pressure-time curves are given in Figure 13.

\section{Boot damage assessment}

Damage suffered by boots after the blast was evaluated separately for sole, vamp and deflector, and mass before and after the blast were compared. For all sample, boot damage was observed merely on the heel part of the shoes where the mine was placed. Boots were not ruptured completely after the blast and so the mechanical leg inside the boots had no contact with the released dust particles or products such as gasses or smoke. All the tests confirmed this result. Damage occurred on the heels of the boots appeared as tear and rupture of the rubber part. The vamp and shoe lace were not damaged or did not tear on any of the boots. The vamp kept its integrity totally after the blast and was not torn. The most important reason for the integrity of the vamp and sole after the blast is their production via the injection method. This method squeezes the rubber material at high pressure into the sole mold and produces a permanent high-strength bond between the upper and sole of boots.

A polyurethane-based flexible adhesive was used to attach the deflector to the composite plates and honeycomb to the composite plates. Force exerted during the blast acted as an upwards pressure load, so that it was applied to the sole of the boots only as compression deformation. No composite parts, except for the deflector, were removed from the sole. This situation was attributed to deficiency of a dominant shear force during the blast and to the force being exerted as pressure load, substantially. The deflector was removed from the sole because its geometry caused shear force from its sides. 


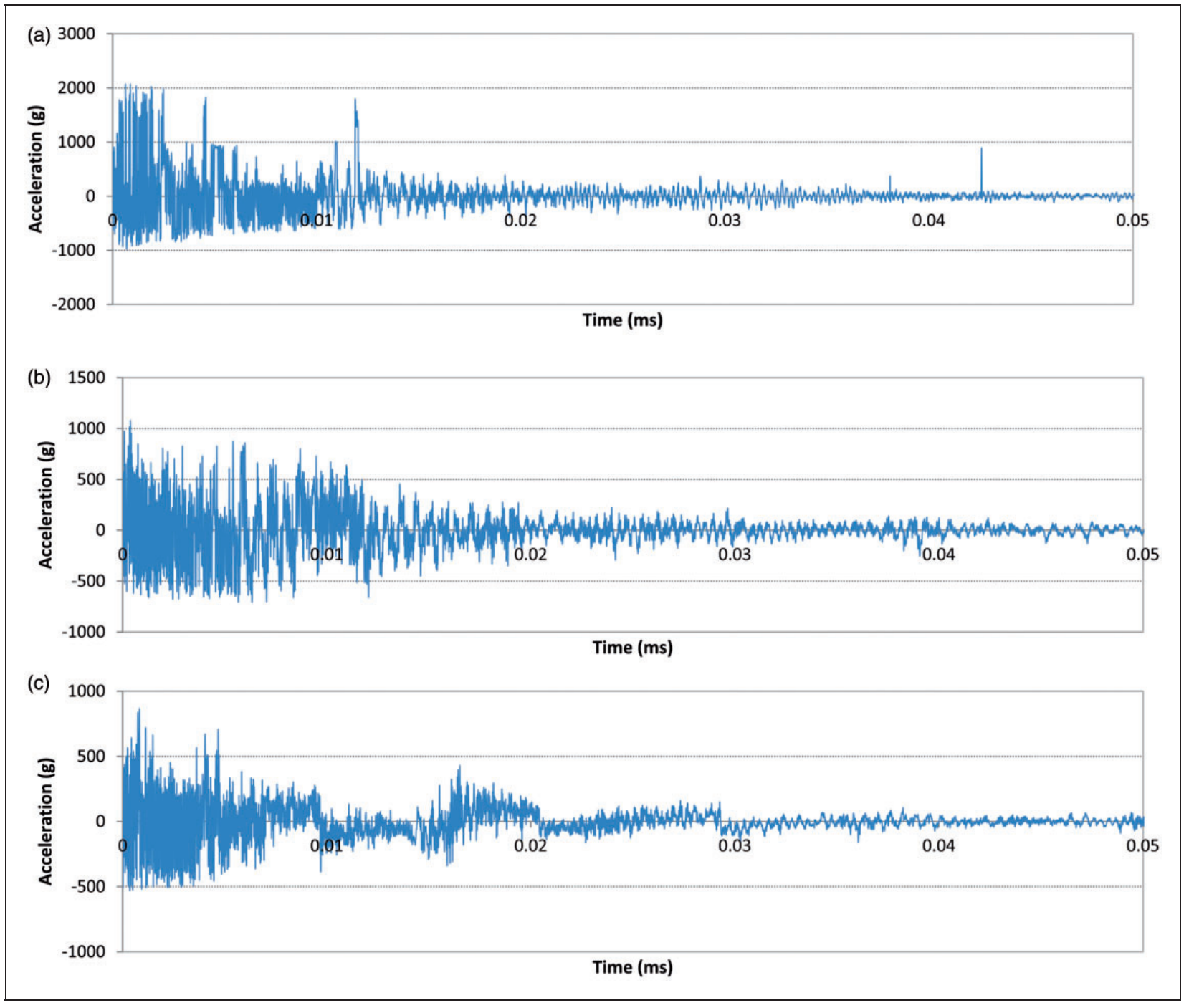

Figure 12. Typical acceleration-time curves of the Type-I (a), Type-2 (b) and Type-3 (c) samples.

Type-1 boot demonstrated critical damage on its heel after the blast. On this part rubber was ruptured through the middle of deflector and unimpaired parts was opened owing to cracking (Figure 14(a) and (b)). The deflector was separated from the sole in several tests, whereas an opposite situation also occurred in other tests. The deflector was flattened and bent upward by about $20-25 \mathrm{~mm}$ and slightly pinched. The honeycomb filling inside the deflector was completely solidified (Figure 14(d)). Examining the cross-section of boots, no deformation, bending or damage was seen on the composite insert (Figure 14(d)). Herewith, the energy absorption mechanism for Type-1 boots is limited only with plastic deformation of the deflector and a large part of the blast load transmitted to tibia axis. The Type- 1 sample had $1750 \mathrm{~g}$ mass while its mass decreased only $3.2 \%$ after the blast and fell to $1694 \mathrm{~g}$.
Loss of mass was merely attributable to the rubber part's rupture.

For the Type- 2 boot, the overall damage is a little different. Damage was limited to the heel of the boots for this sample too. On this part rubber was ruptured, however, no rive or puncture occurred on the boot sole (Figure 15(a) and (b)). In all tests the deflector was separated from the sole during the blast. Damage to the deflector was similar to the Type-1 sample. However, upward bending was only about $10-15 \mathrm{~mm}$, which is less in comparison to Type- 1 sample's deflector (Figure 15(d)). Honeycomb filling inside the deflector was completely solidified similar to that of the Type- 1 sample. The cross-section of Type- 2 is quite different from that of Type-1. In this sample the honeycomb core between the composite skins was compressed with the impact of the upward force, 


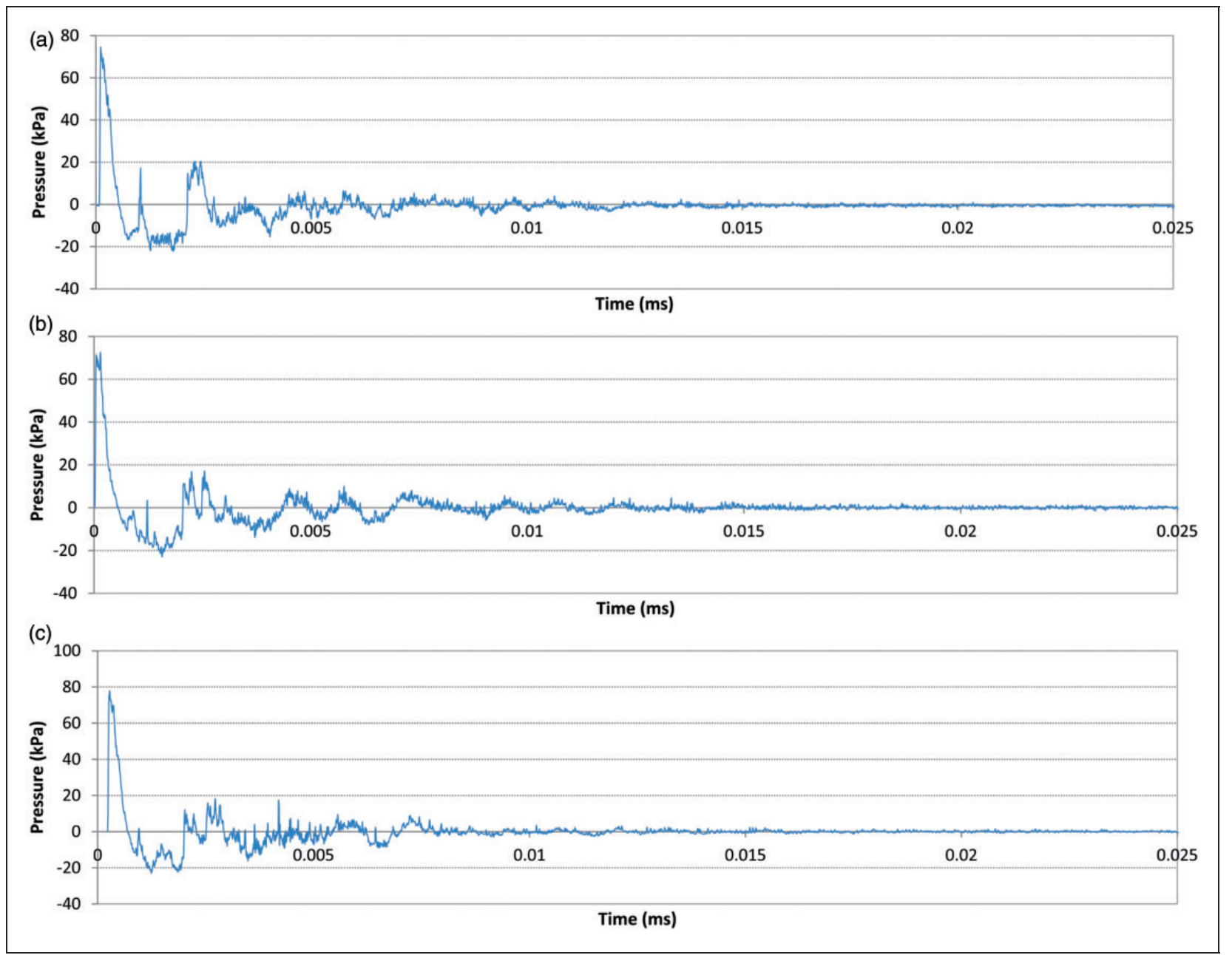

Figure 13. Typical pressure-time curves for the Type-I (a), Type-2 (b) and Type-3 (c) samples.

however, it gained an arch form at the point of the explosive source. Being compressed upwards, the honeycomb filling was broken and sheared off. Then again the honeycomb core was not completely compressed, apart for the portion of the explosive source. Yet the honeycomb layer on the boot sole was not deformed from the midst to the toe (Figure 15(c)). The Type- 2 sample had $1598 \mathrm{~g}$ mass, whereas its mass decreased about $5 \%$ after the blast and fell to $1512 \mathrm{~g}$. Loss of mass was merely attributable to the rubber part's rupture of the heel.

The Type-3 boot was also damaged only from its heel. On this part the rubber was ruptured, however, no rive or puncture occurred on the sole (Figure 16(a) and (b)). In all tests the deflector was separated from the boot sole during the blast. The overall damage of the deflector was observed to be similar to Type- 1 and Type-2 samples. However, upward bending was only about $10 \mathrm{~mm}$ (Figure 16(d)). The honeycomb filling inside the deflector was completely compressed and solidified. The cross-section of the Type-3 sample appears to be quite different from Type-2. In this sample the honeycomb core was uniformly compressed with the impact of the upward force; however, unlike the case for the Type- 2 sample, Type- 3 did not gain an arch form and no rupture occurred. The honeycomb core displays a homogenous compression down to the midst of boot. That it compressed totally, indicates that more energy was absorbed. Also, homogenous compression implies glass beads inside the honeycomb cells spread the load in the plane. The honeycomb core was not deformed from the midst of the boot sole to toe. The Type- 3 sample had $1650 \mathrm{~g}$ mass, whereas its mass decreased about $5 \%$ after the blast and fell to $1567 \mathrm{~g}$. Loss of mass was merely attributable to the rubber part's rupture from the heel.

For all samples, since thermoplastic resin was used for production of composite plates, the composite plates showed no brittle deformation under blast loading. ${ }^{31}$ 


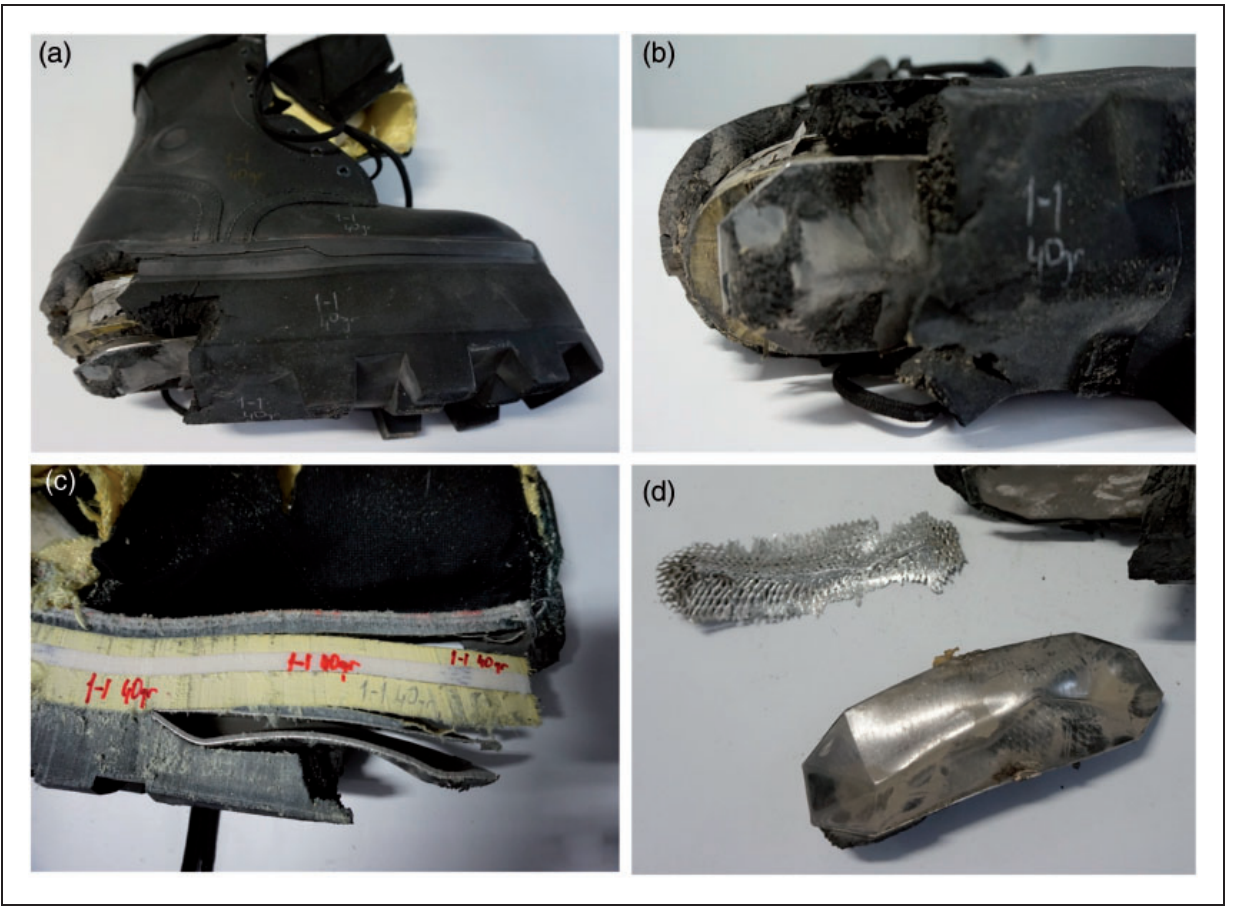

Figure 14. Damage pattern of sample Type-I after the blast test: (a), (b) sole view; (c) cross-section view; and (d) deflector.
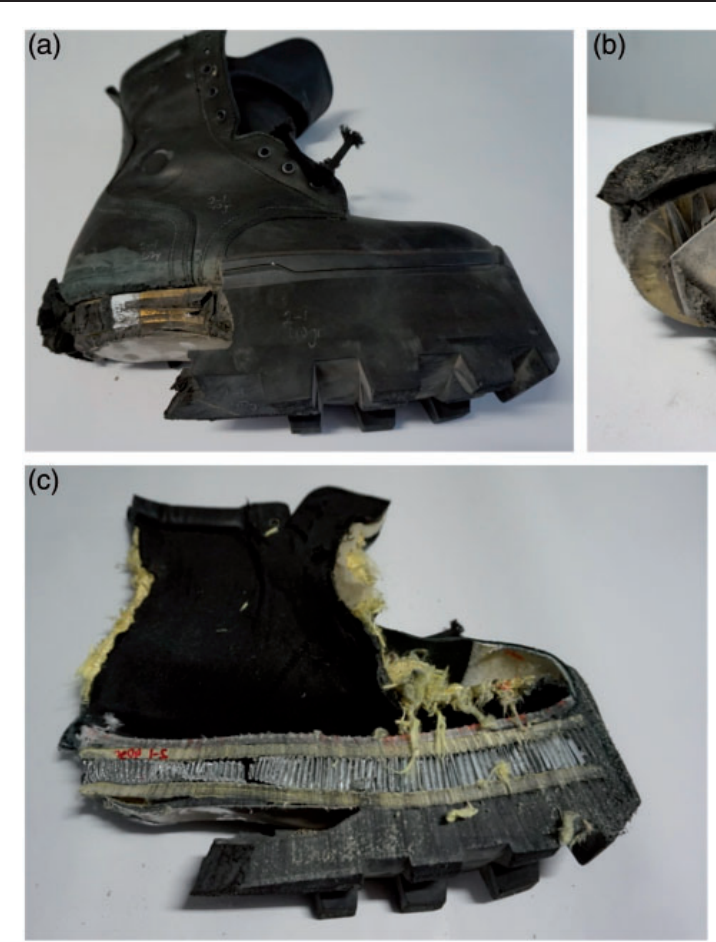
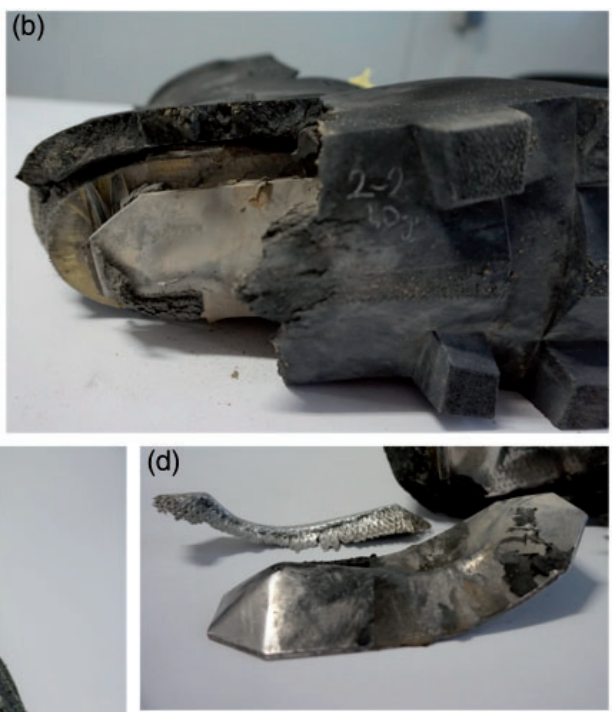

Figure 15. Damage pattern of sample Type-2 after the blast test: (a), (b) sole view; (c) cross-section view; and (d) deflector. 


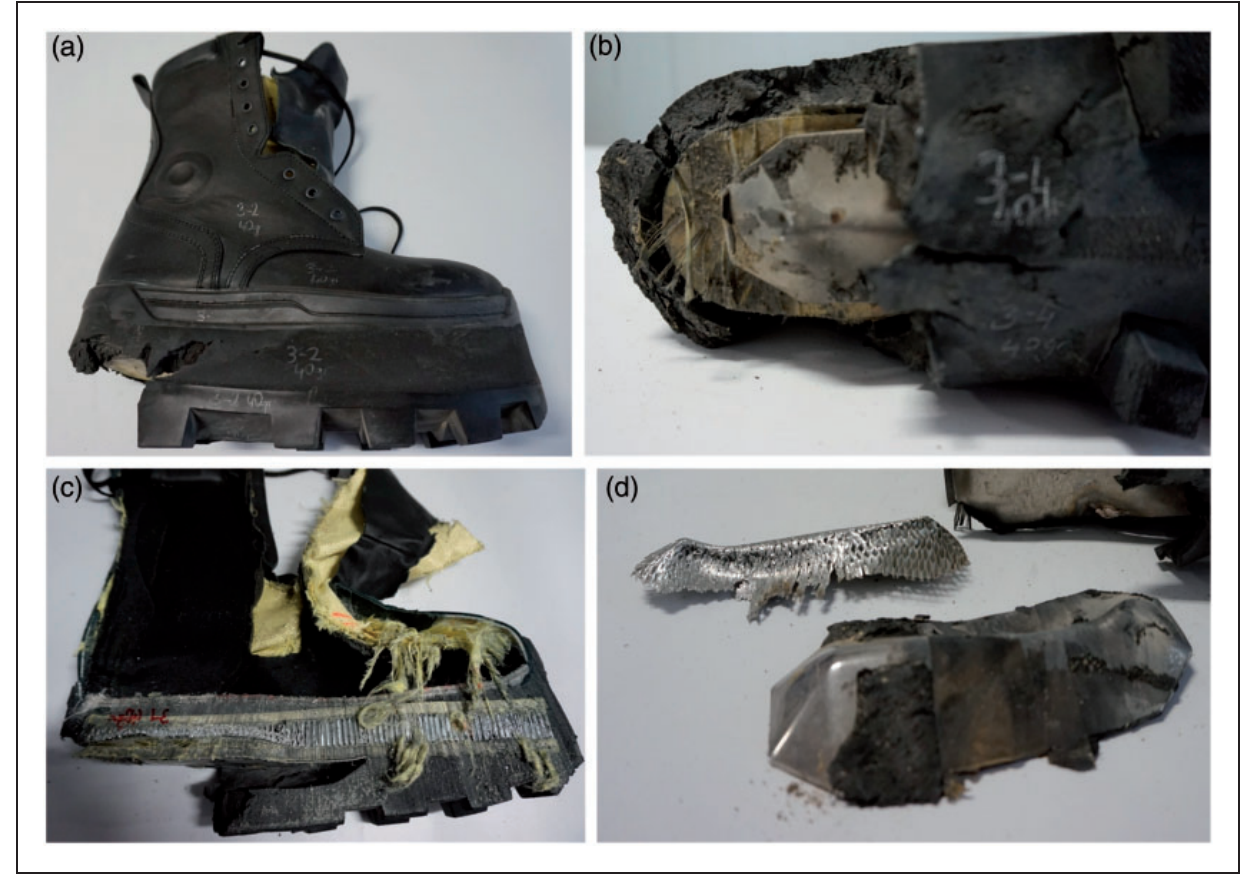

Figure 16. Damage pattern of sample Type-3 after the blast test: (a), (b) sole view; (c) cross-section view; and (d) deflector.

\section{Conclusions}

This study presents the test results of experiments performed with a mechanical leg model in order to compare protection efficiency and energy absorption of different mine boots. The applied test method was compatible with previous studies. ${ }^{8,32}$ The results that have been achieved are as follows.

- If only a monolithic composite layer is used in a protective boot sole, this leads to direct transmission of the load inflicted from the blast. In other words it is not able to absorb energy.

- Using sandwich composites with compressible core material on protective boot sole provides a better energy absorption. The Type- 2 boot sample whose sole has this form reduced the load transmitted through the tibia axis $48 \%$, in comparison to Type-1 boot whose sole has just a monolithic composite layer.

- Filling honeycomb cells with glass microspheres increased the energy absorption dramatically. In the Type-3 sample which was produced in this way, load transmitted through the tibia axis decreased $209 \%$ in comparison to the Type- 1 sample and 59\% in comparison to the Type- 2 sample. Damage assessments and cross-sectional appearances of boot samples support this result.
- Aluminum honeycomb core sandwich composite material filled with glass microspheres was also employed for the Type-3 sample. This is an innovative candidate for production of blast protective armor, as well as mine boots, owing to its high energy absorption capability.

- To evaluate Type-3 sample's protection efficiency in a more detailed way, the same test will be continued by employing a frangible leg model.

\section{Declaration of conflicting interests}

The authors declared no potential conflicts of interest with respect to the research, authorship and/or publication of this article.

\section{Funding}

The authors received no financial support for the research, authorship, and/or publication of this article.

\section{References}

1. Shariful I, Makris A and Bergeron D. The Spider Boot: An effective foot protective systems against anti-personnel mine blasts. J Mine Action, June-2000.

2. Traverso LW, Johnson DE, Fleming A, et al. Combat casualties in Northern Thailand: emphasis on land mine injuries and levels of amputation. Mil Med 1981; 146: 682-685. 
3. Makris A. L'Abbe R.J., Voisine P., et al. Anti-personel mine foot protection systems. US patent no: 6.006.646, 1999.

4. Krohn HF, Flynn RM and Sasaman WO. Protective footpad assembly. US patent no. 2.720.714, August 15, 1952.

5. Chavet I and Madmoni A. Minefield shoe and method for manufacture thereof. US2003/0172554 A1, September 18, 2003.

6. Ringler S and Chavet I. Device for reducing the danger of accidental detonation of a landmine. US patent no: 4.611.411, September 16, 1986.

7. Jordan RD. Protective footgear. US patent no. 3.516.181, June 23, 1970.

8. Fujinaka ES, Barron ER Macdonald JL, et al. Blast protective footwear. US patent no: 3.318.024, May 31, 1996.

9. Vaz GA. Protective boot and sole structure. US patent no: 6.425.193.B2, July 30, 2002.

10. Vaz GA. Blast and fragment resistant safety boot footwear. US patent no: 5.979.081, November 9, 1999.

11. Joynt VP and Dyk JTV. Protective footwear. US 2006/ 0000117 A1, January 5, 2006.

12. Zeman P. Anti land mine-boots. WO 03/037125 A1, October 29, 2001.

13. Lohrmann HR. Anti-personnel mine protective footpad. US patent no: 5.992.056, November 30, 1999.

14. Peche JP, Gaultier R and Peltzer MO. Appliance for protecting against the effects of explosive devices. US patent no: 6.655.051, December 2, 2003.

15. Trimble $\mathrm{K}$ and Clasper J. Anti-personel mine injury; mechanism and medical management. J R Army Med Corps 2001; 147: 73-79.

16. Hanssen AG, Enstock L and Langseth M. Close-range blast loading of aluminum foam panels. Int $J$ Impact Engng 2002; 27: 593-618.

17. van Bree J.L.M.J., "HFM/ET007 Position paper", HFM-ET-007 Meeting, Brussels Belgium, 22 February 2000.

18. Coffey CG, Torrance K, Lonson D, et al. Design, construction and commissioning of a surrogate human leg test facility. Amtech Report TR9775.2701, Rev. 1, November 1999.
19. Roberts I. MOD DCTA Antimine Boot. HFM-ET-007 Meeting, Brussels, Belgium, 22 February 2000.

20. Harris R, Mannion S and Rountree S. The effects of antipersonnel blast mines on the lower extremity. HFM-ET-007 Meeting, Brussels Belgium, 22 February 2000.

21. Kamberoğlu M, Karahan M, Alpdoğan C, et al. Evaluation of foot protection effectiveness against AP mine blast: Effect of deflector geometry. J Testing Eval 2017; 45(1): 1-15. DOI: 10.1520/JTE20150171.

22. Bass CR, Boggess B, Davis M, et al. A methodology for evaluating personal protective equipment for AP landmines. Proceedings of the 2001 UXO conference, New Orleans, USA, April 2001.

23. Hou W, Zhu F, Lu G, et al. Ballistic impact experiments of metallic sandwich panels with aluminum foam core. Int J Impact Engng 2010; 37(10): 1045-1055.

24. Mohan K, Yip TH, Idapalati S, et al. Impact response of aluminum foam core sandwich structures. Mater Sci Engng A 2011; 259: 94-101.

25. Wadley HNG, Dharmasena KP, O’Masta MR, et al. Impact response of aluminum corrugated core sandwich panels. Int J Impact Engng 2013; 62: 114-128.

26. Karahan M, Karahan N, Gül H, et al. Quasi-static behavior of three-dimensional integrated core sandwich composites under compression loading. J Reinf Plastics Compos 2013; 32(5): 289-299.

27. Shah $\mathrm{CH}$, Palm T, Dyer TA, et al. End gaps of filled honeycomb. US7048986 B2, May 2006.

28. Howat EF. Foam filled cellular structural. US3970324 A, June 1976.

29. Mayes AM. Glass transition of amorphous polymer surfaces. Macromolecules 1994; 27(11): 3114-3115.

30. Buchan PA and Chen JF. Blast resistance of FRP composites and polymer strengthened concrete and masonry structures - a state-of-the-art review. Composites: Part B 2007; 38: 509-522.

31. Karahan M. Comparison of ballistic performance and energy absorption capabilities of woven and unidirectional aramid fabrics. Text Res $J$ 2008; 78(8): 718-730.

32. NATO-RTO-TR-HFM-089 AC/323 (HFM-089) TP/51. Test methodologies for personal protection equipment against anti-personnel mine blast, March 2004. 